\title{
Soil chemical attributes and energetic potential of agricultural residual biomasses provided by 23-year soil management
}

Letícia de Pierri ${ }^{1, \star}$, Volnei Pauletti ${ }^{1}$, Gabriel Barth², Antônio Carlos Vargas Motta ${ }^{1}$, Dimas Agostinho da Silva ${ }^{3}$, Luciano Antunes da Roza ${ }^{1}$, Cesar Augusto Schmid Saudade ${ }^{1}$

1.Universidade Federal do Paraná - Solos e Engenharia Agrícola - Curitiba (PR), Brazil.

2.Fundação $A B C$ - Solos e Nutrição de Plantas - Castro (PR), Brazil.

3.Universidade Federal do Paraná - Engenharia Florestal - Curitiba (PR), Brazil.

ABSTRACT: Residual biomass from grains has potential as an energetic source. Biomass composition determines this potential and is related to plant nutrition, which may vary according to soil fertility. The aim of this 23-year field study was to evaluate changes in chemical attributes of a Brazilian Oxisol and in the energetic potential of oat (Avena sativa L.) and soybean (Glycine max (L.) Merr) residual biomasses provided by tillage systems and fertilizer rates. The trial was performed since 1989 , assessing soil chemical attributes in no-tillage (NT), conventional (CT), minimum (MT) and no-tillage plus chisel plough (NT+CP), with two fertilizer rates (normal and reduced, since 1994). Oat and soybean (2012/2013) residual biomasses were collected and analyzed by its elemental composition, higher heating value (HHV) and theoretical potential for electricity production. The NT system presented higher P-resin availability; NT and NT+CP provided higher OM and total P content on soil surface. Without appropriate amounts of $\mathrm{K}$ and $\mathrm{P}$ fertilizer, $\mathrm{P}$-resin and $\mathrm{P}$ total contents diminished mainly in 0-0.1 m depth, while exchangeable, non-exchangeable and total $\mathrm{K}^{+}$fractions were mined even in deeper layers $(0-0.3 \mathrm{~m})$. The better general fertility conditions were achieved by conservative tillage systems, with normal fertilizer rate. Soil fertility levels changed chemical composition of both biomasses but had no effect on biomass HHV. Considering a system with oat and soybean grain production plus residual biomasses for energetic exploitation, it could be possible to generate $2,941 \mathrm{GWh} \cdot \mathrm{year}^{-1}$, while still achieving $70 \%$ residue coverage under no-tillage maintenance.

Key words: bioenergy, no-tillage, fertilization, Avena sativa L., Glycine $\max ($ L.) Merr. 


\section{INTRODUCTION}

The world population has surpassed 7.5 billion inhabitants, resulting in a steady increase demand for food, fiber and energy. In an attempt to supply the growing energy demand the use of alternative sources such as biomass has increased considerably along recent decades (Ambrosio et al. 2017).

Soil erosion and water loss control have been the main reasons for no-tillage adoption worldwide (Derpsch et al. 2010). In southern Brazil, most of the grain crops are managed under no-tillage, which leaves large amounts of residue on soil surface. Excessive biomass accumulation may impede germination and promote the spread of diseases in the following rotation, especially in this mild weather region. Nevertheless, studies show that up to $30 \%$ of crop residues can be removed for bioenergy production while maintaining 93\% residue coverage to protect the soil (Andrews 2006). This strategy has potential to support sustainable food and energy production, since the energy output will be originated from normal biomass resources generated under conditions that promote soil conservation.

The energetic potential of agricultural residues has been defined mainly on the basis of its higher heating value (HHV) (Telmo and Lousada 2011), elemental composition (Sheng and Azevedo 2005) and ash content (Tan and Lagerkvist 2011), characteristics that are closely related to crop management and plant nutrition (Ambrosio et al. 2017).

Tillage and fertilization practices modify soil chemical, physical and biological attributes (Mbuthia et al. 2015; Valboa et al. 2015), thereby contributing to differences in soil nutrient availability and creating contrasting environments for crop development. Plants absorb mainly labile fraction of nutrients, though previous studies have demonstrated the contribution of soil structural sources to plant nutrition (Zhang et al. 2011). Because soil properties are strongly buffered, many years can be required to detect changes due to management (Kibet et al. 2016; Valboa et al. 2015), which necessitates long-term studies to better understand the processes involved.

The aim of this 23-year field study was to evaluate changes in chemical attributes of a Brazilian Oxisol and in the energetic potential of oat (Avena sativa L.) and soybean (Glycine max (L.) Merr) residual biomasses provided by tillage systems and fertilizer rates. We hypothesize that long-term tillage and fertilizer practices change soil chemical attributes, providing a different nutritional environment for crop growth, which may reflect in the energetic value of the residual biomass.

\section{MATERIALS AND METHODS}

\section{Experimental conditions}

The experiment was performed in Ponta Grossa (Paraná state, Brazil) since 1989 ( $25^{\circ} 00^{\prime} 53^{\prime \prime}$ S; 50 $00^{\circ} 07^{\prime \prime}$ W; elevation: $910 \mathrm{~m}$ ), in a sandy clay Oxisol (450 g. $\mathrm{kg}^{-1}$ clay, $450 \mathrm{~g} \cdot \mathrm{kg}^{-1}$ sand and $100 \mathrm{~g} \cdot \mathrm{kg}^{-1}$ silt), in gentle slope and subtropical climate (Cfb).

Eight treatments were arranged in split-block scheme under a randomized block design with three replications in $104.12 \mathrm{~m}^{2}$ plots. The treatments were a combination of four soil tillage systems and two fertilizer rates. The tillage systems studied were: 1) CT - conventional tillage with one disk plowing and two light disking; 2) MT - minimum tillage, with one medium and one light disking; 3) NT - no-tillage, seeding with no tillage; and 4) NT+ $\mathrm{CP}$ - no-tillage plus chisel plough, held in winter every three years. Two fertilizer rates were used, namely: 1) normal rate with fertilization based on the recommendation of a local survey, which consisted of fertilization during sowing $\left(\mathrm{N}-\mathrm{P}_{2} \mathrm{O}_{5}-\mathrm{K}_{2} \mathrm{O}\right)$ and later by topdressing nitrogen $(\mathrm{N})$ on the standing Poaceae; 2 ) reduced rate, no $\mathrm{P}$ and $\mathrm{K}$ was applied and $\mathrm{N}$ was applied only by top dressing on the standing Poaceae, the same amount applied as in the normal rate. From the period of 1989 until 1994, however, all the plots were conducted under the normal rate of fertilization, in which the fertilizer suppression has started since 1994. All fertilizer rates and the crop rotation scheme adopted throughout the experiment are shown in Table 1.

In 1989 it was applied $304.5 \mathrm{~kg} \cdot \mathrm{ha}^{-1}$ of $\mathrm{P}_{2} \mathrm{O}_{5}$ (Yookarin $®$ ) and $162 \mathrm{~kg} \cdot \mathrm{ha}^{-1}$ of $\mathrm{K}_{2} \mathrm{O}(\mathrm{KCl})$ in all plots, incorporated at $0.3 \mathrm{~m}$ depth. Equally, limestone was applied to all plots in 1989 (7.3 Mg.ha $\left.{ }^{-1}\right), 1992$ and 1994 (2.0 Mg.ha ${ }^{-1}$ each). The first liming was incorporated at $0.3 \mathrm{~m}$ depth and the two other applications were performed by broadcasting before sowing.

\section{Soil chemical attributes}

The soil was sampled in 2012 using a manual soil sampling in the depths of $0.0-0.10,0.10-0.20$ and $0.20-0.30 \mathrm{~m}$ 
Table 1. Fertilizations $\mathrm{N}-\mathrm{P}_{2} \mathrm{O}_{5}-\mathrm{K}_{2} \mathrm{O}$ held in long-term experiment with four soil tillage methods (no-tillage, conventional tillage, minimum tillage and no-tillage plus chisel plough) in Ponta Grossa, Paraná state, Brazil.

\begin{tabular}{|c|c|c|c|c|c|c|c|}
\hline \multirow{3}{*}{ Season } & \multirow{3}{*}{ Crop } & \multicolumn{2}{|c|}{ Fertilizer rates } & \multirow{3}{*}{ Season } & \multirow{3}{*}{ Crop } & \multicolumn{2}{|c|}{ Fertilizer rates } \\
\hline & & Normal & Reduced & & & Normal & Reduced \\
\hline & & \multicolumn{2}{|c|}{$\left(\mathbf{k g} \cdot \mathbf{h a}^{-1}\right)$} & & & \multicolumn{2}{|c|}{$\left(\mathrm{kg} \cdot \mathrm{ha}^{-1}\right)$} \\
\hline 1989 & black oat & \multicolumn{2}{|c|}{-} & 2001 & wheat & $20(+60)^{\star}-40-40$ & $60-00-00$ \\
\hline $89 / 1990$ & soybean & \multicolumn{2}{|c|}{$00-40-40$} & $01 / 2002$ & soybean & $00-40-40$ & - \\
\hline 1990 & lupine & \multicolumn{2}{|c|}{-} & 2002 & black oat & - & - \\
\hline 90/1991 & maize & \multicolumn{2}{|c|}{$30(+80)-90-48$} & $02 / 2003$ & maize & $30(+90)-60-60$ & $90-00-00$ \\
\hline 1991 & oat & \multicolumn{2}{|c|}{-} & 2003 & oat & $20(+45)-40-40$ & $45-00-00$ \\
\hline $91 / 1992$ & soybean & \multicolumn{2}{|c|}{$00-40-40$} & $03 / 2004$ & soybean & $00-40-40$ & - \\
\hline 1992 & wheat & \multicolumn{2}{|c|}{$10(+40)-20-20$} & 2004 & wheat & $24(+45)-90-60$ & $45-00-00$ \\
\hline $92 / 1993$ & soybean & \multicolumn{2}{|c|}{$00-40-40$} & $04 / 2005$ & soybean & $00-40-40$ & - \\
\hline 1993 & vetch & \multicolumn{2}{|c|}{ - } & 2005 & black oat & - & - \\
\hline $93 / 1994$ & maize & \multicolumn{2}{|c|}{$30(+80)-90-48$} & $05 / 2006$ & maize & $30(+130)-60-60$ & $130-00-00$ \\
\hline 1994 & oat & \multicolumn{2}{|c|}{-} & 2006 & oat & $30(+67.5)-60-60$ & $67.5-00-00$ \\
\hline $94 / 1995$ & soybean & $00-60-60$ & - & $06 / 2007$ & soybean & $00-50-50$ & - \\
\hline 1995 & wheat & $10(+40)-20-20$ & $40-00-00$ & 2007 & wheat & $30(+67.5)-60-60$ & $67.5-00-00$ \\
\hline $95 / 1996$ & soybean & $00-60-60$ & - & 07/2008 & soybean & $00-60-60$ & - \\
\hline 1996 & vetch & - & - & 2008 & black oat & - & - \\
\hline $96 / 1997$ & maize & $36(+80)-72-48$ & $80-00-00$ & $08 / 2009$ & maize & $36(+135)-96-90$ & $135-00-00$ \\
\hline 1997 & black oat & - & - & 2009 & oat & $30(+45)-60-60$ & $45-00-00$ \\
\hline $97 / 1998$ & soybean & $00-60-60$ & - & 09/2010 & soybean & $00-60-60$ & - \\
\hline 1998 & wheat & $00(+60)-40-40$ & $60-00-00$ & 2010 & wheat & $30(+67.5)-60-60$ & $67.5-00-00$ \\
\hline $98 / 1999$ & soybean & $00-40-40$ & - & $10 / 2011$ & soybean & $00-60-60$ & - \\
\hline 1999 & black oat & - & - & 2011 & black oat & - & - \\
\hline $99 / 2000$ & maize & $30(+90)-60-60$ & $90-00-00$ & $11 / 2012$ & maize & $36(+135)-96-90$ & $135-00-00$ \\
\hline 2000 & oat & - & - & 2012 & oat & $16(+76.5)-60-70$ & $76.5-00-00$ \\
\hline $00 / 2001$ & soybean & $00-40-40$ & - & $12 / 2013$ & soybean & $00-60-60$ & - \\
\hline
\end{tabular}

*Values in parentheses in the normal rate of fertilization refer to additional nitrogen (reduced rate of fertilization received only this nitrogen application on maize, wheat and oat crops). All plots received normal rate from 1989 to 1994.

(15 sub-samples each plot). Afterwards, soil samples were air-dried, sieved $(2 \mathrm{~mm})$ and $\mathrm{pH}\left(\mathrm{CaCl}_{2}\right), \mathrm{H}+\mathrm{Al}$, exchangeable bases ( $\mathrm{Ca}, \mathrm{Mg}$ e $\mathrm{K}$ ), available $\mathrm{P}$ by resin extraction, and organic carbon were determined (Raij et al. 2001). The parameters organic matter (OM), base saturation (V\%), aluminum saturation $(\mathrm{m} \%)$ and cation exchange capacity (CEC) were calculated from the laboratory results.

The sum of the fractions $\mathrm{K}^{+}$exchangeable plus $\mathrm{K}^{+}$nonexchangeable was obtained by extraction with $\mathrm{HNO}_{3} 1 \mathrm{M}$ at $113^{\circ} \mathrm{C}$ for $30 \mathrm{~min}$ and determination by flame photometry. Non-exchangeable $\mathrm{K}^{+}$was estimated as the difference between $\mathrm{K}$ extracted by $\mathrm{HNO}_{3}$ and by ion exchange resin. Total $\mathrm{P}$ and $\mathrm{K}$ were obtained by microwave soil digestions $\left(200{ }^{\circ} \mathrm{C}, 1000 \mathrm{~W}\right)$ using $\mathrm{HNO}_{3}, \mathrm{HF}$ and $\mathrm{H}_{2} \mathrm{O}_{2}$ (USEPA - 3052 method), filtering and determination by ICP-OES and flame photometry, respectively.

\section{Biomasses energetic characterization}

In the 2012/2013 growing season, oat (URS Guapa cultivar) and soybean (NA5909RG cultivar) were cultivated and the weed, pest and disease controls were performed according to the recommendations for each species. The seeds were inoculated with Rhizobium every time that soybean was the summer crop. Cumulative precipitation during the development of both crops was 1,174 mm (July/2012March/2013), with low rainfall during the initial period of oat development. The rainfall during the oat crop cycle in 
2012 was $32 \%$ lower than the historical average rainfall of the ten years prior (Fig. 1).

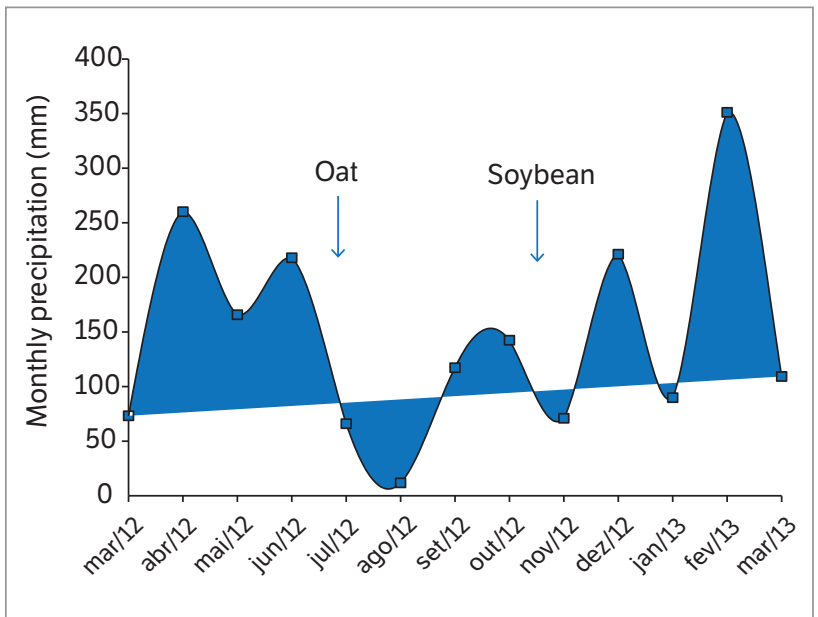

Figure 1. Precipitation ( $\mathrm{mm}$ ) in Ponta Grossa, Paraná state, Brazil, between March/2012 and March/2013 (SEAB2013, adapted). Arrows indicate sowing dates for oat (06/29/2012) and soybean (11/16/2012).

At the point of physiological maturity, the harvest was conducted with a plot harvester machine. Samples were separated in grain and residual biomass, and it was calculated the residual biomass and grain yield by correcting moisture to $130 \mathrm{~g} \cdot \mathrm{kg}^{-1}$. Additionally, the residual biomass remaining in the field (due to the cutting height) was collected and added to the harvested residual biomass in order to calculate the total residual biomass.

After correcting the total residual biomass to kg of dry matter (drying at $60^{\circ} \mathrm{C}$ ), sub-samples were ground in a Wiley knife mill (20 mesh size) and the concentrations of $\mathrm{C}, \mathrm{H}, \mathrm{O}$, $\mathrm{N}$ and $\mathrm{S}$ in the biomass were determined by dry combustion. The elements $\mathrm{P}, \mathrm{K}, \mathrm{Ca}, \mathrm{Mg}, \mathrm{Na}, \mathrm{Fe}, \mathrm{Cu}, \mathrm{Mn}$ and $\mathrm{Zn}$ were extracted by acid digestion (Martins and Reissmann 2007) and the element Si by basic digestion (Furlani and Gallo 1978), with subsequent determination by ICP-OES. After obtaining the concentrations of each element, the nutrient content was calculated considering the total residual biomass produced by each species.

The biomass ash contents were quantified by burning the samples at $550{ }^{\circ} \mathrm{C}$ during $3 \mathrm{~h}$. Lignin, hemicellulose and cellulose composition was obtained by bromatological analysis as described in Berchielli et al. (2001), only for the contrasting treatments (NT with normal fertilization and the CT with reduced fertilization).

The HHV was determined using an adiabatic calorimeter model IKA®-WERKE C5000 according to standard 8633 of the Brazilian Association of Technical Standards (ABNT 1984). From biomass $H$ concentrations, the lower heating value (LHV) on a dry basis was determined according to Kollmann and Cotê (1968) (Eq. 1):

$$
\mathrm{LHV}=\mathrm{HHV}-600 \times 9 \times(\mathrm{H} / 100)
$$

where LHV is the lower heating value, in $\mathrm{kcal}^{\mathrm{kg}} \mathrm{kg}^{-1}$; HHV, the higher heating value, in $\mathrm{kcal} \mathrm{kg}^{-1} ; 600$, the latent heat of vaporization of water at $20^{\circ} \mathrm{C}$, in $\mathrm{kcal}^{\circ} \mathrm{kg}^{-1} ; 9$, the mass of water formed in the combustion per each $1 \mathrm{~kg}$ of $\mathrm{H}$ in the biomass, in $\mathrm{kg}$; and $\mathrm{H}$, the hydrogen concentration in the biomass, in \%.

Finally, for the conversion of $\mathrm{HHV}$ values to the theoretical potential for electrical energy production it was used the Eq. 2, based on Andrews (2006), EPE (2014) and Nogueira and Lora (2003):

$$
\mathrm{EPP}=\{[\mathrm{TRB} \times \mathrm{LHV} \times 0.3] / 860\} \times 0.2
$$

where EPP is the electrical production potential, in $\mathrm{kWh} \cdot \mathrm{ha}^{-1}$; $\mathrm{TRB}$, total residual biomass, in $\mathrm{kg}^{-\mathrm{ha}^{-1}}$; LHV, lower heating value, in $\mathrm{kcal} \cdot \mathrm{kg}^{-1} ; 0.3$ (30\%) the percentage of total residual biomass removal from the field which still allows sufficient coverage to no-tillage; 860 , equivalence between the kcal and $\mathrm{kWh}$ units; and 0.2 the average electric conversion efficiency (20\%) of boilers.

\section{Statistical analysis}

The Bartlett test was used to verify the homogeneity of variances ( $p>0.05)$, followed by ANOVA. When significant, the factorial treatments were compared by Tukey test at $5 \%$ probability, except for the lignin, cellulose and hemicellulose, in which statistical analysis was not performed. For soil parameters, each depth was analyzed independently. In addition, correlations among variables were analyzed by Pearson linear coefficient method. All statistical analyses were performed using $R \circledast$ statistical software version 2.15.1.

\section{RESULTS AND DISCUSSION Soil chemical attributes}

There was no effect of tillage on chemical attributes up to $0.30 \mathrm{~m}$ depth while fertilizer rates promoted changes but 
restricted to the 0.0-0.10 m layer (Figs. 2 and 3). Moreover, the interaction effect between tillage systems and fertilizer rates was observed for $\mathrm{OM}, \mathrm{Mg}^{2+}$ and P-resin contents in 0.0-0.10 m layer (Figs. 2 to 4 ).

Long-term reduction on fertilizer application resulted in higher soil pH until $0.20 \mathrm{~m}$ (Fig. 2b, upper axis). Acidification by nitrification process and higher cationic bases exported when full fertilizer rate was applied could explain the results (Congreves et al. 2015). Agreeing with soil pH, potential acidity $(\mathrm{H}+\mathrm{Al})$ was higher under full fertilizer rate but differing only within 0-10 cm depth (Fig. 2b, bottom axis).

According to the evaluations made by Pauletti et al. (2005) in this same area in 1994 (and thus, before the fertilization suppression), the $\mathrm{pH}$ values ranged between 6.0 and 6.1 in $0.0-0.10 \mathrm{~m} ; 5.6$ and 6.0 in $0.10-0.20 \mathrm{~m}$; and 5.1 and 5.6 in 0.20-0.30 m. Our results, however, showed that soil acidity decreased over depth regardless of treatment. This could be expected since all lime applications, exceptionally at the beginning of the experiment, were made to the soil surface and the subsoil acidity may be ameliorated by surfaceapplied amendments (Cifu et al. 2004) due to the leaching of small limestone particles. It can be either noticed that the three liming applications throughout 23 years were able to buffer the $\mathrm{pH}$ above 4.8 until $0.30 \mathrm{~m}$ depth (Figs. $2 \mathrm{a}$ and $2 b$ ), confirming the long-term residual effect of liming (Cifu et al. 2004).

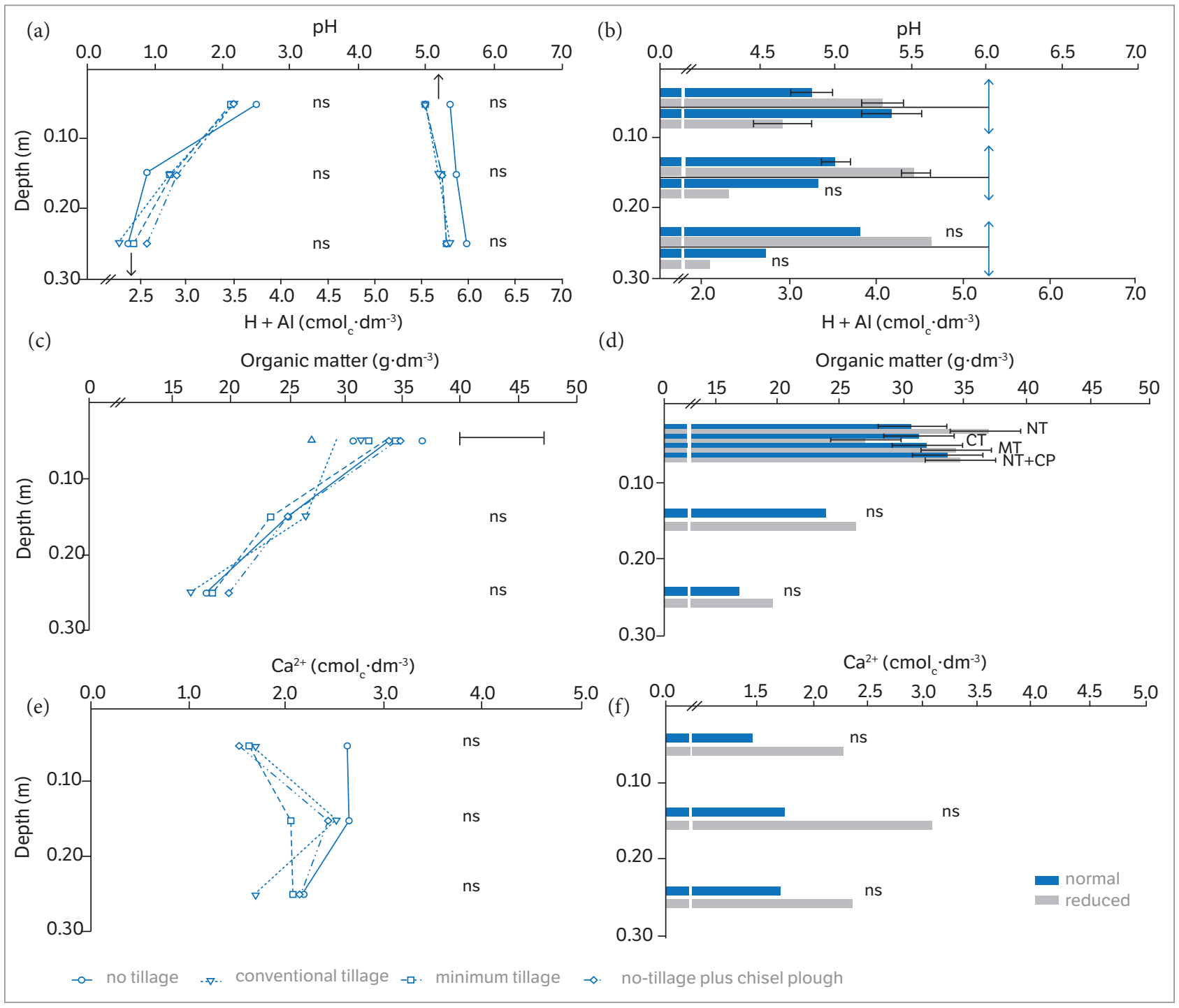

Figure 2. (a) and (b) $\mathrm{pH}$ and $\mathrm{H}^{+}+\mathrm{Al}^{3+}$; (c) and (d) organic matter; and (e) and (f) $\mathrm{Ca}^{2+}$ contents of a Brazilian Oxisol (0.0-0.10, 0.10-0.20 and 0.20-0.30 m depth) according to soil tillage methods. Rods indicate the honestly significant difference (Tukey, $p<0.05)$; ns: non-significant. First layer (0-0.1 $\mathrm{m}$ depth) to organic matter ( $\mathrm{c}$ and $\mathrm{d}$ ): interaction between tillage and fertilizer rates. 


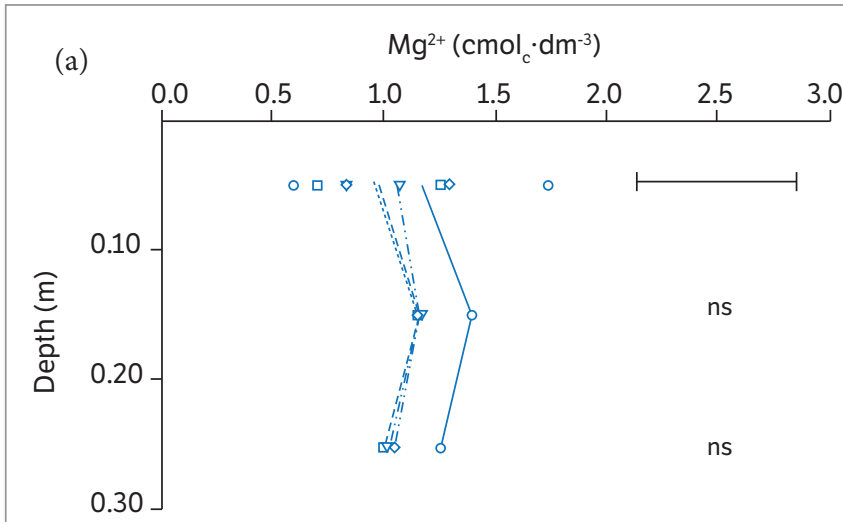

(b) $\quad \mathrm{Mg}^{2+}\left(\mathrm{cmol}_{\mathrm{c}} \cdot \mathrm{dm}^{-3}\right)$
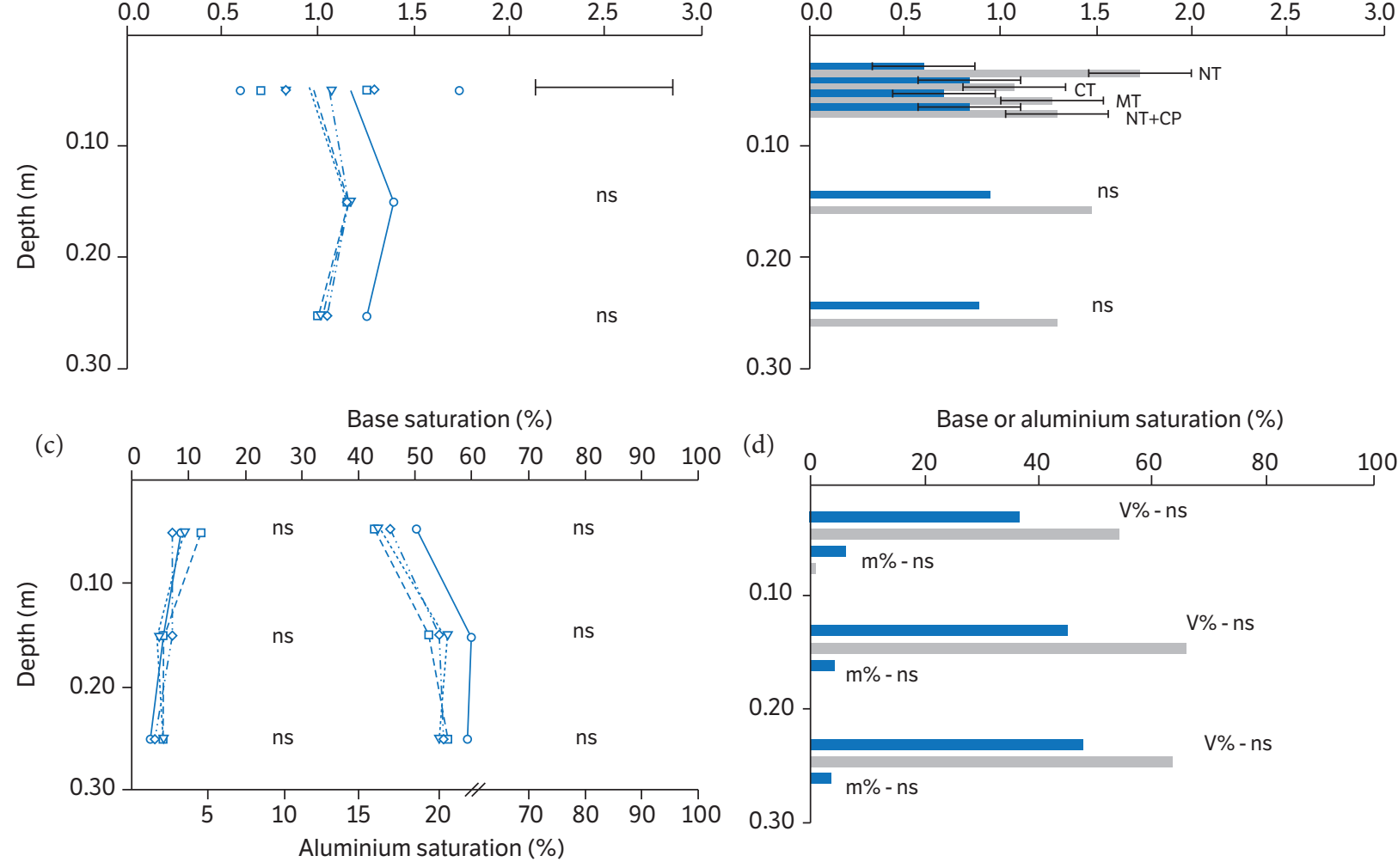

(e) $\mathrm{CEC}\left(\mathrm{cmol}_{\mathrm{c}} \cdot \mathrm{dm}^{-3}\right)$

(f)
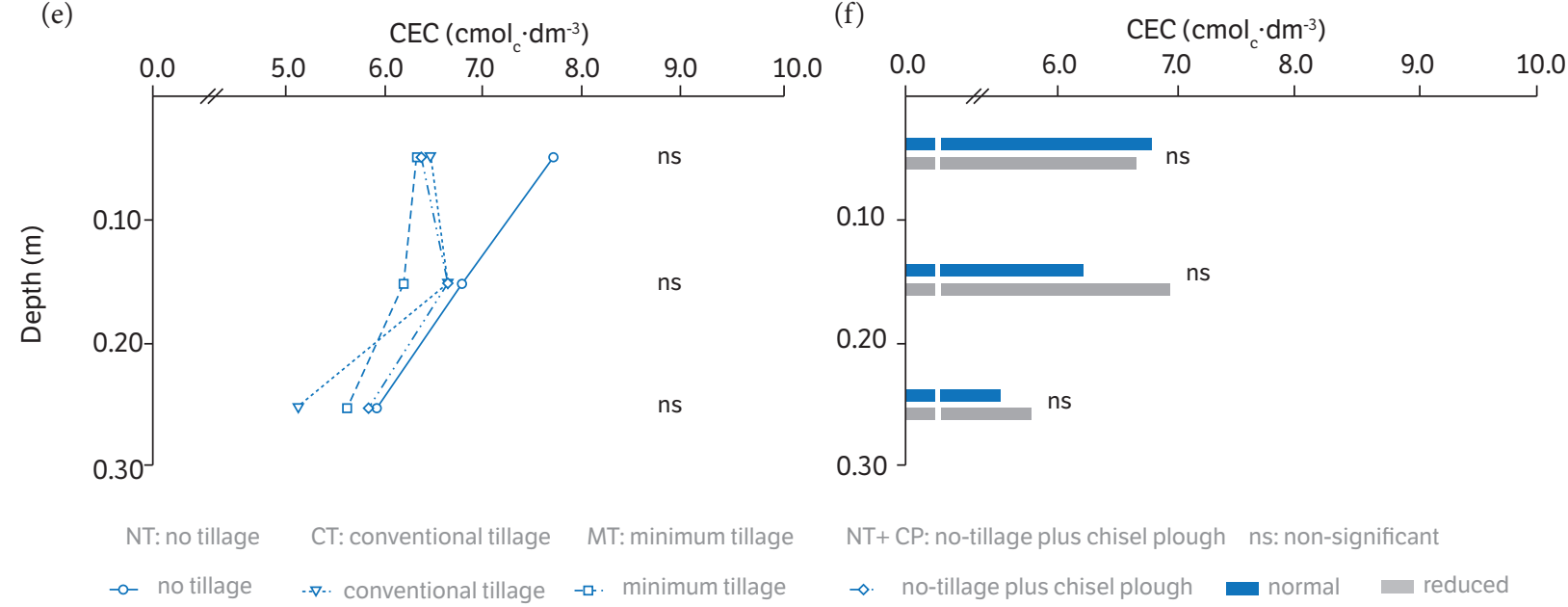

Figure 3. (a) and (b) $\mathrm{Mg}^{2+}$ content; (c) and (d) base saturation and aluminum saturation; (d) and (f) cation exchange capacity (CEC) of a Brazilian Oxisol (0.0-0.10, $0.10-0.20$ and $0.20-0.30 \mathrm{~m}$ depth) according to soil tillage methods and fertilizer rates. Rods indicate the honestly significant difference (Tukey, $\mathrm{p}<0.05)$; ns: non-significant. First layer (0-0.1 m depth) to $\mathrm{Mg}^{2+}(\mathrm{a})$ and $(\mathrm{b})$ : interaction between tillage and fertilizer rates.

The NT system with the reduced rate of fertilizer had the highest amount of OM in 0.0-0.10 m. The opposite occurred in CT, i.e., in this tillage system it was observed the lowest amount of OM when fertilization was suppressed (Figs. 2c and 2d). Although it was firstly expected that the OM decomposition would be faster with higher $\mathrm{N}$ input (normal rate of fertilizer), this result can be explained by a priming effect inducement, which may be stimulated when the microbial community seeks nutrients for its metabolism, contributing to OM mining (Dimassi et al. 2014). Besides, CT system causes inversion and burial of the organic residues in deepest layers, increasing soil-residue contact and, thus, 


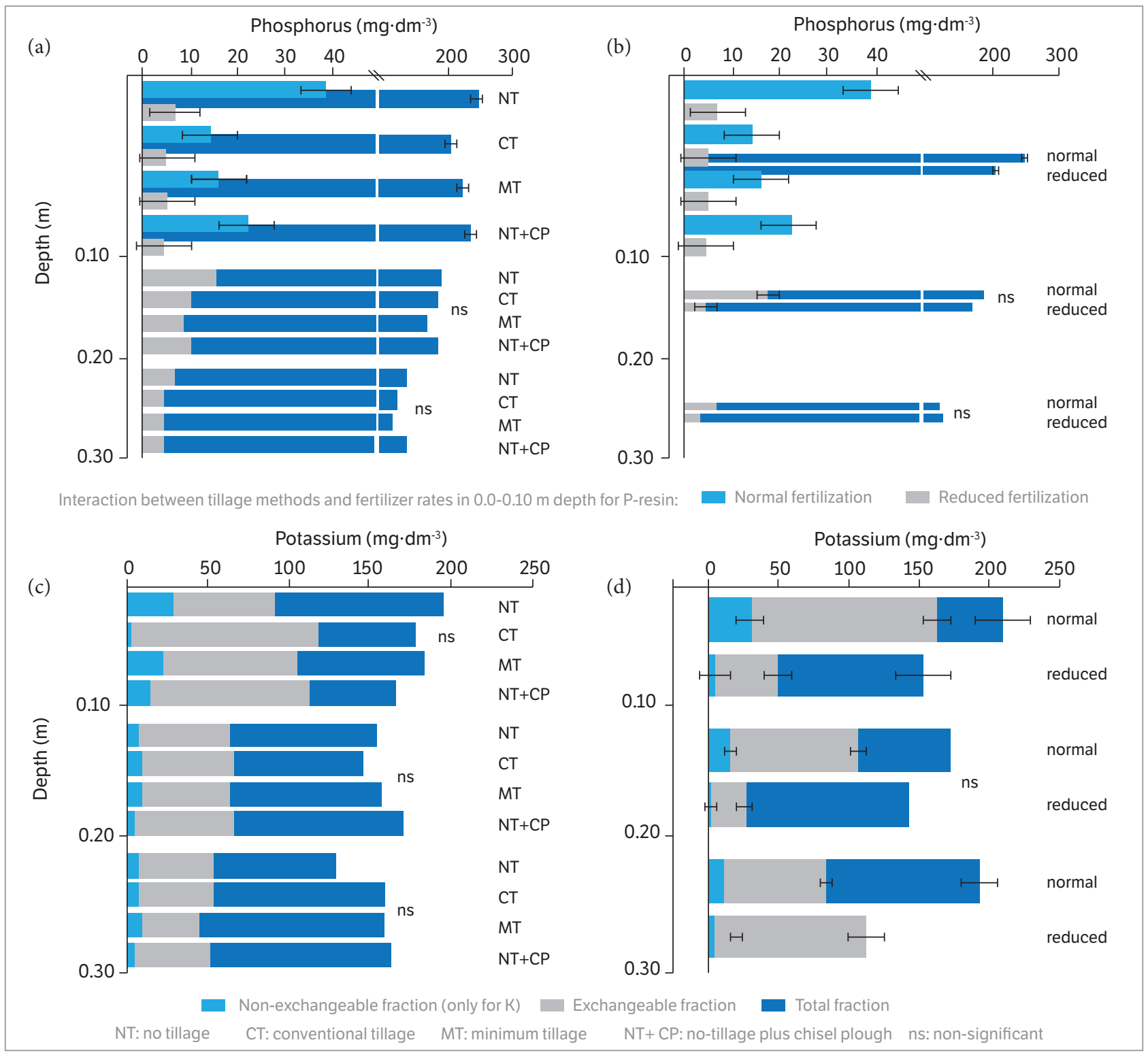

Figure 4. (a) and (b) Phosphorus (P); and (c) and (d) potassium (K) contents in a Brazilian Oxisol (0.0-0.10, 0.10-0.20 and 0.20-0.30 m depth) according to soil tillage methods and fertilizer rates (normal and reduced). Rods indicate the honestly significant difference (Tukey, $\mathrm{p}<0.05)$; ns: non-significant.

further stimulating OM oxidation (Kibet et al. 2016). On the other hand, higher contents and superficial OM accumulation in conservative tillage systems is widely reported in many papers (Derpsch et al. 2010; Valboa et al. 2015; Vogeler et al. 2009) due to slower OM turnover as a consequence of non-disturbance on soil (Kibet et al. 2016). It is important to highlight, however, that in this same area Pauletti et al. (2005) reported close OM contents to ours within 0.0-0.10 m depth (NT: $37.8 \mathrm{~g} \cdot \mathrm{dm}^{-3}$; CT: $36.1 \mathrm{~g} \cdot \mathrm{dm}^{-3} ;$ MT: $37.8 \mathrm{~g} \cdot \mathrm{dm}^{-3}$; and $\mathrm{NT}+\mathrm{CP}: 43.0 \mathrm{~g} \cdot \mathrm{dm}^{-3}$ ), which can be an indicative of an OM content steady state over time.
Soil chemical attributes seem to respond more slowly to soil management than biological attributes, requiring a longer time for the effects to be recognized (Kibet et al. 2016; Mbuthia et al. 2015). The differences also have been related to sampling depth (Congreves et al. 2015; Dimassi et al. 2014) and site-specific properties (Valboa et al. 2015; Zhang et al. 2015). In this sense, even after 23 years it was not possible to identify differences regarding soil management on $\mathrm{Ca}^{2+}$ availability (Figs. 2e and 2f), V\%, $\mathrm{m} \%$ and potential CEC, exceptionally to $\mathrm{Mg}^{2+}$ content in the first layer (Fig. 3). Significant tillage effects have been reported in previous studies 
with more stratified samples (Deubel et al. 2011; Dimassi et al. 2014). Comparing the normal fertilizer rate with the soil analysis performed by Pauletti et al. (2005) in 1994, however, it can be noted that higher cationic base exportation occurred in these plots, since $\mathrm{Ca}^{2+}$ and $\mathrm{Mg}^{2+}$ contents and V\% decreased in 1.1 to 3-fold over time.

The interaction between soil tillage and fertilizer rates regarding P-resin within 0.0-0.10 m depth resulted in higher content of this nutrient in conservative tillage systems (NT and $\mathrm{NT}+\mathrm{CP}$ ) when normal fertilizer rate was adopted (Figs. $4 \mathrm{a}$ and $4 \mathrm{~b}$ ), which is addressed to the surficial application and low mobility of $\mathrm{P}$ in soil (Messiga et al. 2012). Considering that the $\mathrm{P}$ suppression started in 1994, after 18 years without $\mathrm{P}$ application, it was observed depletion in the superficial layers for NT and $\mathrm{NT}+\mathrm{CP}$ systems in about $35 \%$, but the same was not observed for CT and MT systems. On the other hand, with normal rate of fertilizer, the available $\mathrm{P}$ buildup occurred for all tillage systems, increasing the P-resin contents in $0.0-0.10 \mathrm{~m}$ in 2.7 to 3.5 times (Pauletti et al. 2005). Regarding the current data, the reduced rate of fertilizer accounted for $18 \%, 35 \%, 33 \%$ and $21 \%$ of P-resin contents found in NT, CT, MT and NT+CP systems, respectively, in comparison with normal rate of fertilizer (Figs. $4 \mathrm{a}$ and $4 \mathrm{~b}$ ). The $\mathrm{P}$ reduction extended until 0.0-0.20 m depth, indicating root exploration. It is possible that under NT growth root concentrated close to soil surface, increasing P uptake and depletion. Additionally, NT system had 2.7 times higher available $\mathrm{P}$ than in CT in the same fertilizer rate. This can be associated with higher $\mathrm{P}$ adsorption sites in $\mathrm{CT}$ provided by soil exposure (Al-Kaisi and Kwaw-Mensah 2007), once there was no indication of erosion and runoff due to the landscape condition.

It was observed main effects of both tillage systems and fertilizer rates regarding total $\mathrm{P}$ within $0.0-0.10 \mathrm{~m}$ depth, with higher amounts for NT and in normal rate (Figs. 4a and 4b). Although it appears that long-term phosphate fertilization has been reflected in total $\mathrm{P}$ contents, low contribution of P-resin was accounted to this fraction ( $3 \%$ up to $10 \%$ ) as a consequence of high P fixation.

There was no influence of tillage systems in any $\mathrm{K}$ fraction, contrasting with large effects of $\mathrm{K}$ fertilization. Exceptionally for the non-exchangeable fraction at $0.20-0.30 \mathrm{~m}$ and the total fraction at $0.10-0.20 \mathrm{~m}$ depths, all the others $\mathrm{K}$ fractions were higher in normal fertilizer rate up to $0.30 \mathrm{~m}$ (Figs. $4 \mathrm{c}$ and $4 \mathrm{~d}$ ). The average exchangeable K contents reported by Pauletti et al. (2005) before nutrient suppression has started indicates that the reduced fertilizer rate declined this fraction in 2.7 to 3.0 -fold within 0.0-0.30 $\mathrm{m}$ over the years. Like $\mathrm{P}$, the result reinforces the exhaustion of $\mathrm{K}$ without reposition. On the other hand, $\mathrm{K}$ decrease extends in depth due to higher $\mathrm{K}$ mobility in comparison to $\mathrm{P}$ and the normal rate of fertilizer kept exchangeable $\mathrm{K}$ contents constant over time ( $\mathrm{K}$ exchangeable contents within $0.0-0.10 \mathrm{~m}$ reported by Pauletti et al. (2005) in 1994 were: 164, 133, 156 and $156 \mathrm{mg} \cdot \mathrm{dm}^{-3}$ to NT, CT, MT and NT+CP, respectively).

Most of the total $\mathrm{K}$ is represented by the exchangeable fraction, mainly in 0.0-0.10 m depth and when normal fertilizer rate was applied (Fig. 4d). As annual additions of potassium fertilizers maintained exchangeable $\mathrm{K}^{+}$contents up to 3.0 folds in comparison to reduced rate, this may have been reflected in the total contents. In deeper layers, there was a considerable reduction of the exchangeable $\mathrm{K}^{+}$but total contents remained slightly altered. Thus, it is an indicative that soil minerals (e.g. mica and feldspars) had contributed more to total $\mathrm{K}$ contents in $0.10-0.20$ and $0.20-0.30 \mathrm{~m}$ layers, whereas potassium fertilizers seemed to supply total $\mathrm{K}$ in $0.0-0.10 \mathrm{~m}$.

The reduction in the exchangeable $\mathrm{K}^{+}$fraction after 18 years without fertilization, in comparison to the normal rate, was $69 \%, 75 \%$ and $76 \%$ in $0.0-0.10,0.10-0.20$ and $0.20-0.30 \mathrm{~m}$, respectively. Nonetheless, regarding the nonexchangeable fraction, the reduction was $88 \%, 90 \%$ and $73 \%$ for the same conditions. This may mean that there was higher depletion of non-exchangeable $\mathrm{K}^{+}$fraction in the upper layers due to potassium fertilization restriction. Previous authors have discussed the contribution of non-exchangeable $\mathrm{K}^{+}$fraction to plant nutrition (Zhang et al. 2011) especially when there was limitation on $K$ availability.

In order to verify how $\mathrm{K}$ and $\mathrm{P}$ fertilization negligence on long-term affects soil reserves, it was calculated the element's stock until $0.3 \mathrm{~m}$ depth based on $\mathrm{P}$ and $\mathrm{K}$ total contents previously measured and the soil bulk density, according to the excavation method proposed by Blake and Hartge (1986) to the depths 0-0.05, 0.05-0.10, $0.10-0.20$ and $0.20-0.30 \mathrm{~m}$. The single measures of $0-0.05$ and $0.05-0.10 \mathrm{~m}$ layers were converted to an arithmetic average value of $0.0-0.10 \mathrm{~m}$ depth. Then, a correction 
was made from the equivalent soil mass, to avoid any differences regarding soil bulk densities among tillage systems (Sisti et al. 2004), taking as a reference the CT with reduced fertilization (Eq. 3).

$$
\begin{aligned}
\text { stock } & =\sum_{i=1}^{n-1} P i \text { or } K i+\left[M_{n}-\right. \\
& \left.-\left(\sum_{i=1}^{n} M_{i}-\sum_{i=1}^{n} M_{R i}\right)\right] \cdot\left[\frac{P_{n} \text { ou } K_{n}}{M_{n}}\right]
\end{aligned}
$$

where $\sum_{\mathrm{i}=1}^{\mathrm{n}-1} \mathrm{P}_{\mathrm{i}}$ orK $\mathrm{i}$ are the stock of $\mathrm{P}$ or $\mathrm{K}$ from the first to the penultimate layer; $M_{n}$ is the soil mass in the deepest layer; $M_{i}$ is the soil mass from the first to the deepest layer; $M_{R i}$ is the soil mass from the first to the deepest layer, in CT with reduced fertilization; and $P_{n}$ or $K_{n}$ are the $\mathrm{P}$ or K stock in the deepest layer (all data in $\mathrm{Mg} \cdot \mathrm{ha}^{-1}$ ).

The K stock was influenced by fertilization diminishing in $301.8 \mathrm{~kg} \cdot \mathrm{ha}^{-1}$ (approximately $13 \mathrm{~kg} \cdot \mathrm{ha}^{-1} \cdot \mathrm{year}^{-1}$ ), while the $\mathrm{P}$ stock was not affected by restriction in $\mathrm{P}$ fertilization, with a difference between normal and reduced rates of $46.3 \mathrm{~kg} \cdot \mathrm{ha}^{-1}$ (Fig. 5). This result contrasted with the sharp decrease described for P availability within $0.0-0.10 \mathrm{~m}$. The $\mathrm{P}$ fertilization in the experiment establishment $\left(304.5 \mathrm{~kg} \cdot \mathrm{ha}^{-1}\right.$ of $\mathrm{P}_{2} \mathrm{O}_{5}$ ) could have contributed to supply $\mathrm{P}$ due to residual effect, since possibly structural forms might not provide $\mathrm{P}$ to plant nutrition under restriction of this element in soil. Otherwise, non-exchangeable $\mathrm{K}^{+}$fractions supplied the plant nutrition in the reduced fertilizer rate, resulting in a mining of soil natural resources. Additionally, deeper soil layers may have supplied K nutrition to plants (Zhang et al. 2011), what was not accounted in the stock calculations.
Despite some of the soil chemical attributes had not showed response to the treatments, this long-term experiment demonstrated that better fertility condition and, as a consequence, better crop environment regarding soil nutrition was achieved with conservative tillage systems and following the fertilization scheme to replace nutrients exported by harvesting, which is in agreement with the main literature (Congreves et al. 2015; Mbuthia et al. 2015; Zhang et al. 2015). This management provided non-depletion of natural soil reserves and maintenance of OM contents over time, with the additional benefit of soil protection against wind and water erosion.

\section{Biomasses energetic characterization}

There was no interaction between soil tillage systems and fertilizer rates regarding grain yield and total residual biomass for both cultures, but the two crops responded differently to the treatments. Crop yield may be changed when conventional tillage is replaced for less intensive soil revolving systems such as no-tillage. However, these responses are complex and seem to differ among geographical regions and species, resulting in yield increment (Zhang et al. 2015), decrease (Messiga et al. 2012) or no change (Vogeler et al. 2009).

Oat presented higher grain yield in NT system than in CT (Fig. 6a), which may be attributed to better general fertility in the arable layer in that system, as previously discussed. Also, higher total residual biomass was observed to oat in NT and NT+CP (Fig. 6b). However, soybean grain yield and total residual biomass were not influenced by tillage methods, with 3,207 and 2,185 $\mathrm{kg} \cdot \mathrm{ha}^{-1}$ on average, respectively.

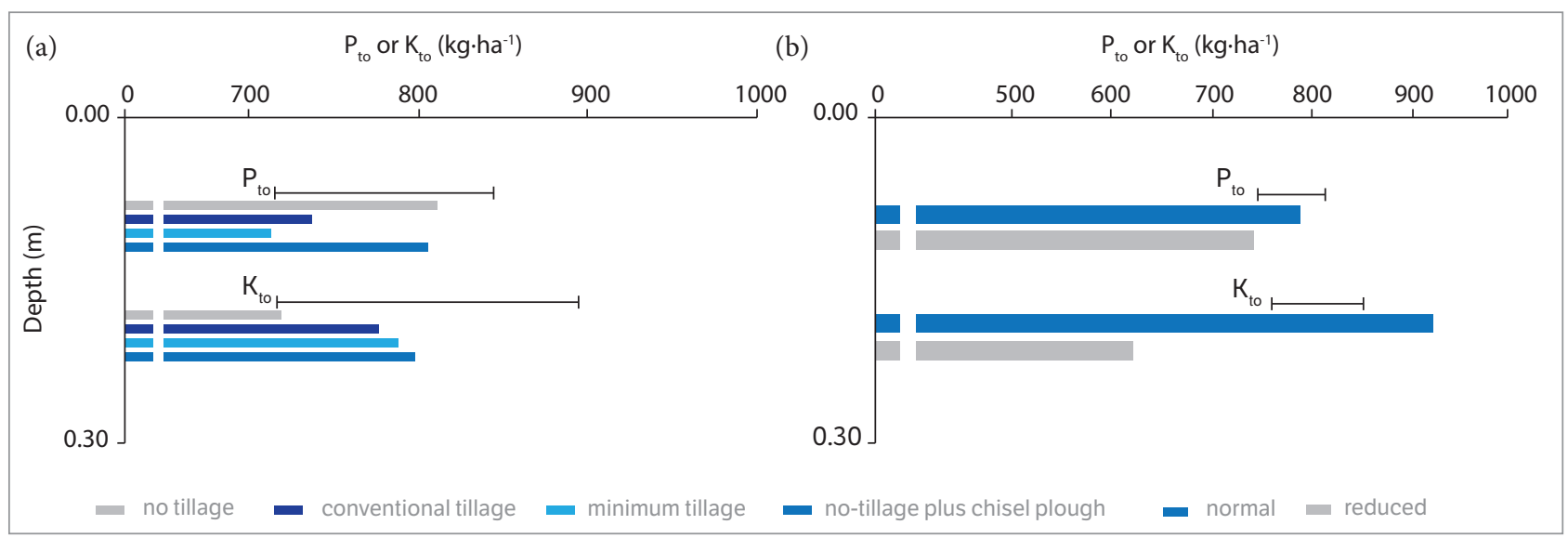

Figure 5. Total stock of phosphorus ( $P$ ) and potassium (K) of a Brazilian Oxisol (0-0.30 m depth) according to (a) four soil tillage methods, and (b) two fertilizer rates (normal and reduced) after 23 management years (average of three replicates). Rods indicate the honestly significant difference (Tukey, $\mathrm{p}<0.05$ ). 


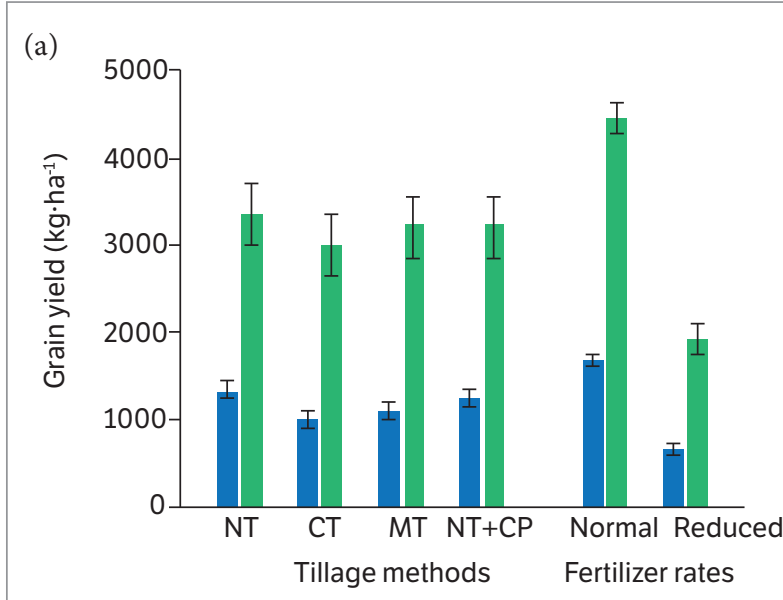

(b)

(c)
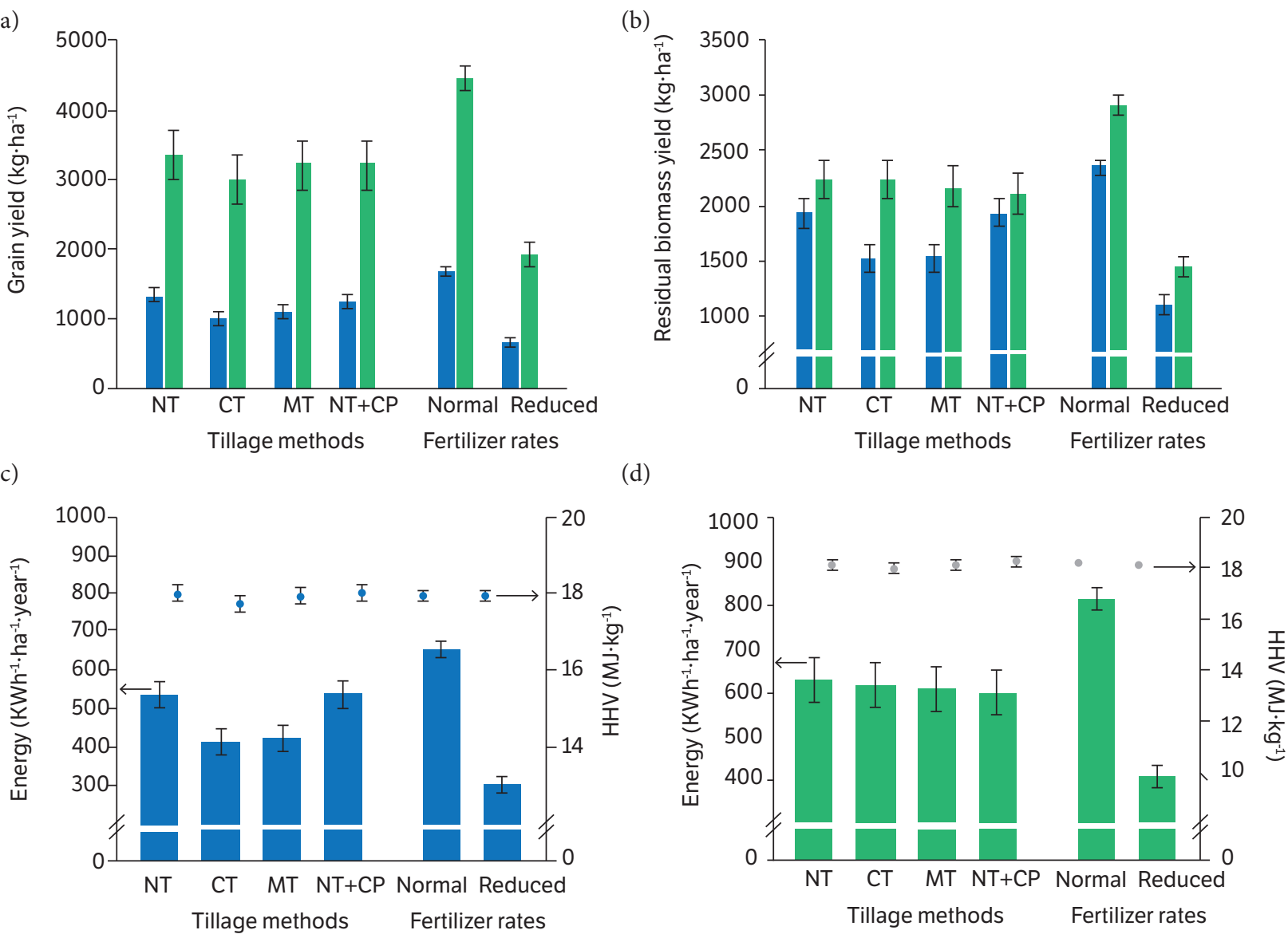

NT: no tillage

CT: conventional tillage

MT: minimum tillage

NT+ CP: no-tillage plus chisel plough

Figure 6. (a) Grain and (b) residual biomass yield; (c) and (d) theoretical potential for electricity production and higher heating value (HHV) of oat (blue) and soybean (green) according to soil tillage methods and fertilizer rates (normal and reduced). Rods indicate the honestly significant difference (Tukey, $\mathrm{p}<0.05$ ).

Difference response to tillage systems between oat and soybean could be addressed to water availability, since oat grew under water restriction (Fig. 1) and conservative tillage systems promotes higher soil humidity maintenance (Zhang et al. 2015).

Soil tillage and fertilizer management influenced nutrient dynamics in soil, which leads to alteration in nutrient use efficiency (Al-Kaisi and Kwaw-Mensah 2007). Although there was no influence of tillage systems on soybean yields, fertilization efficiency with $\mathrm{P}$ and $\mathrm{K}$ in NT increased approximately $6 \mathrm{~kg} \cdot \mathrm{ha}^{-1}$ of soybeans for every $1 \mathrm{~kg} \cdot \mathrm{ha}^{-1}$ of $\mathrm{P}_{2} \mathrm{O}_{5}$ and $\mathrm{K}_{2} \mathrm{O}$ applied when compared to the CT. As expected, reduction in fertilizer application diminished grain and residual biomass yields for both crops. Oat produced 2.5 times more grain and 2.1 times more residual biomass in the normal rate compared to the reduced one. Soybean yield increased 2.3 and 1.9 fold under the same condition for grains and residual biomass, respectively.

Biomass composition affects their energetic quality because the minerals remain virtually unchanged after burning in boilers, since they do not participate in the combustion process. All the nutrient contents that responded to the treatments were observed in those that provided higher biomass yields (Table 2). $\mathrm{Ca}$ and $\mathrm{Mg}$ contents were higher in $\mathrm{NT}$ and $\mathrm{NT}+\mathrm{CP}$ for oat, which had higher biomass in these systems, and did not differ for soybean, that had the same yield in all tillage. Similarly, nutrient contents were always higher in the normal rate of fertilizer than in the reduced rate, which corresponds to the higher yields found.

The normal fertilizer rate increased the levels of $\mathrm{P}$ and $\mathrm{K}$ in the biomass in 3.5 and 4 fold until 0.0-0.20 m, compared to the reduced rate. Because of this, there was a considerable 
Table 2. Nutrient content, ash content and chemical fractionation in the residual biomass of oat (season 2012) and soybean (season 2012/2013) according to soil tillage methods (no-tillage - NT; conventional tillage-CT; minimum tillage-MT; and no-tillage plus chisel plough-NT+CP) and fertilizer rates (normal and reduced).

\begin{tabular}{|c|c|c|c|c|c|c|c|c|}
\hline Nutrient & $\mathbf{N T}^{\star}$ & CT & MT & $\mathrm{NT}+\mathrm{CP}$ & nor. ${ }^{\star \star}$ & red. & \multicolumn{2}{|c|}{ frac. 1} \\
\hline $\mathrm{N}\left(\mathrm{kg} \cdot \mathrm{ha}^{-1}\right)$ & 8.7 & 7.6 & 7.3 & 8.0 & $9.3 a$ & $6.5 b$ & Lignin & 6.0 \\
\hline $\mathrm{Ca}\left(\mathrm{kg} \cdot \mathrm{ha}^{-1}\right)$ & $4.1 \mathrm{a}$ & $3.1 b$ & $3.2 b$ & $3.8 a b$ & $4.6 a$ & $2.5 b$ & Cellulose & 33.7 \\
\hline $\mathrm{Mg}\left(\mathrm{kg} \cdot \mathrm{ha}^{-1}\right)$ & $3.5 a$ & $2.6 \mathrm{~b}$ & $2.6 b$ & $3.1 \mathrm{ab}$ & $3.5 a$ & $2.4 b$ & Hemicellulose & 24.6 \\
\hline $\mathrm{K}\left(\mathrm{kg} \cdot \mathrm{ha}^{-1}\right)$ & 35.4 & 31.3 & 30.6 & 34.6 & $49.5 a$ & $16.5 b$ & & \\
\hline$P\left(k g \cdot h a^{-1}\right)$ & 0.3 & 0.3 & 0.3 & 0.3 & $0.4 a$ & $0.2 b$ & & \\
\hline $\mathrm{Si}\left(\mathrm{kg} \cdot \mathrm{h} \mathrm{a}^{-1}\right)$ & 12.7 & 12.7 & 10.4 & 12.9 & 15.8 & 8.5 & & \\
\hline $\mathrm{Na}\left(\mathrm{g} \cdot \mathrm{ha}^{-1}\right)$ & 634 & 541 & 612 & 786 & $846 a$ & $440 b$ & & \\
\hline $\mathrm{Cu}\left(\mathrm{g} \cdot \mathrm{ha}^{-1}\right)$ & 7.6 & 5.6 & 5.4 & 7.3 & 7.8 & 5.2 & & \\
\hline $\mathrm{Fe}\left(\mathrm{g} \cdot \mathrm{h} \mathrm{a}^{-1}\right)$ & 354 & 320 & 328 & 298 & 361 & 288 & & \\
\hline$M n\left(g \cdot h a^{-1}\right)$ & 125 & 148 & 132 & 172 & 241 & 47.4 & & \\
\hline $\mathrm{Zn}\left(\mathrm{g} \cdot \mathrm{h} \mathrm{a}^{-1}\right)$ & 60.1 & 37.9 & 79.9 & 64.8 & 80.2 & 41.2 & & \\
\hline Ash (\%) & 5.3 & 4.9 & 5.5 & 5.7 & $5.7 a$ & $5.0 \mathrm{~b}$ & & \\
\hline \multicolumn{9}{|c|}{ soybean } \\
\hline $\mathrm{N}\left(\mathrm{kg} \cdot \mathrm{ha}^{-1}\right)$ & 21.3 & 18.2 & 17.8 & 19.2 & $21.4 a$ & $16.9 \mathrm{~b}$ & Lignin & 14.2 \\
\hline $\mathrm{Ca}\left(\mathrm{kg} \cdot \mathrm{ha}^{-1}\right)$ & 9.5 & 9.9 & 8.7 & 9.3 & $11.6 a$ & $7.1 b$ & Cellulose & 36.9 \\
\hline $\mathrm{Mg}\left(\mathrm{kg} \cdot \mathrm{ha}^{-1}\right)$ & 9.9 & 9.9 & 9.0 & 8.9 & $10.7 a$ & $8.2 b$ & Hemicellulose & 16.5 \\
\hline $\mathrm{K}\left(\mathrm{kg} \cdot \mathrm{ha}^{-1}\right)$ & 27.7 & 30.9 & 29.6 & 24.6 & $50.2 a$ & $6.1 \mathrm{~b}$ & & \\
\hline $\mathrm{P}\left(\mathrm{kg} \cdot \mathrm{ha}^{-1}\right)$ & 0.6 & 0.5 & 0.5 & 0.6 & $0.7 a$ & $0.4 \mathrm{~b}$ & & \\
\hline $\mathrm{Si}\left(\mathrm{kg} \cdot \mathrm{ha}^{-1}\right)$ & 0.3 & 0.6 & 0.3 & 0.4 & 0.3 & 0.4 & & \\
\hline $\mathrm{Na}\left(\mathrm{g} \cdot \mathrm{ha} \mathrm{a}^{-1}\right)$ & 449 & 445 & 432 & 421 & $582 a$ & $291 b$ & & \\
\hline $\mathrm{Cu}\left(\mathrm{g} \cdot \mathrm{ha}^{-1}\right)$ & 12.0 & 11.1 & 10.9 & 10.5 & $14.0 a$ & $8.3 b$ & & \\
\hline $\mathrm{Fe}\left(\mathrm{g} \cdot \mathrm{h} \mathrm{a}^{-1}\right)$ & 458 & 575.7 & 549 & 438 & 418 & 593 & & \\
\hline $\mathrm{Mn}\left(\mathrm{g} \cdot \mathrm{ha}^{-1}\right)$ & 36.4 & 43.1 & 37.8 & 38.8 & $57.3 a$ & $20.7 b$ & & \\
\hline $\mathrm{Zn}\left(\mathrm{g} \cdot \mathrm{h} \mathrm{a}^{-1}\right)$ & 31.8 & 31.3 & 37.2 & 34.6 & 36.3 & 31.2 & & \\
\hline Ash (\%) & 4.2 & 3.9 & 4.2 & 4.5 & $4.8 a$ & $3.6 b$ & & \\
\hline
\end{tabular}

Values followed by different letters in the column differ by Tukey test $(p<0.05)$; ns = not significant. * Average values of the two fertilization rates; ** average values of the four soil tillage methods. ${ }^{1}$ no statistical test was performed.

difference of $\mathrm{K}$ contents in both residual biomasses between normal and reduced rates, but regarding $\mathrm{P}$ the maximum difference was 300 g.ha $^{-1}$ (Table 2). This behavior can be associated with the redistribution of elements in the plant since most of the $\mathrm{P}$ absorbed is allocated to the grains (Deubel et al. 2011), while $\mathrm{K}$ absorbed remains mainly in straw (Zhang et al. 2011).

$\mathrm{K}$ was the nutrient that most influenced oat and soybean ash contents, especially when fertilizer was applied (Fig. 7). The biomass ash content was not influenced by tillage systems, but it was higher in the normal fertilizer rate (Table 2). There was a significant correlation between the content of this nutrient in the soil arable layer $(0.0-0.20 \mathrm{~m})$ and the biomass ash contents $(r=0.84$ for soybean and $\mathrm{r}=0.65$ for oat, $\mathrm{p}<0.01$ ) as well as between ash and $\mathrm{K}$ in the biomasses $(\mathrm{r}=0.89$ for soybean and $\mathrm{r}=0.92$ for oat, $\mathrm{p}<0.01$ ) (Figs. 8 and 9). Ash contains several elements that can be reused for nutrient replacement to the soil (Tan and Lagerkvist 2011), especially regarding to $\mathrm{K}$. So, considering that all the biomass is used to energetic production, returning back the ashes to soil could account up to 49.5 and $50.2 \mathrm{~kg} \cdot \mathrm{ha}^{-1}$ of $\mathrm{K}$. However, one negative perspective regarding high $\mathrm{K}$ and $\mathrm{Si}$ contents in biomass is that this may lead to corrosion of boilers and decreased combustion system efficiency 


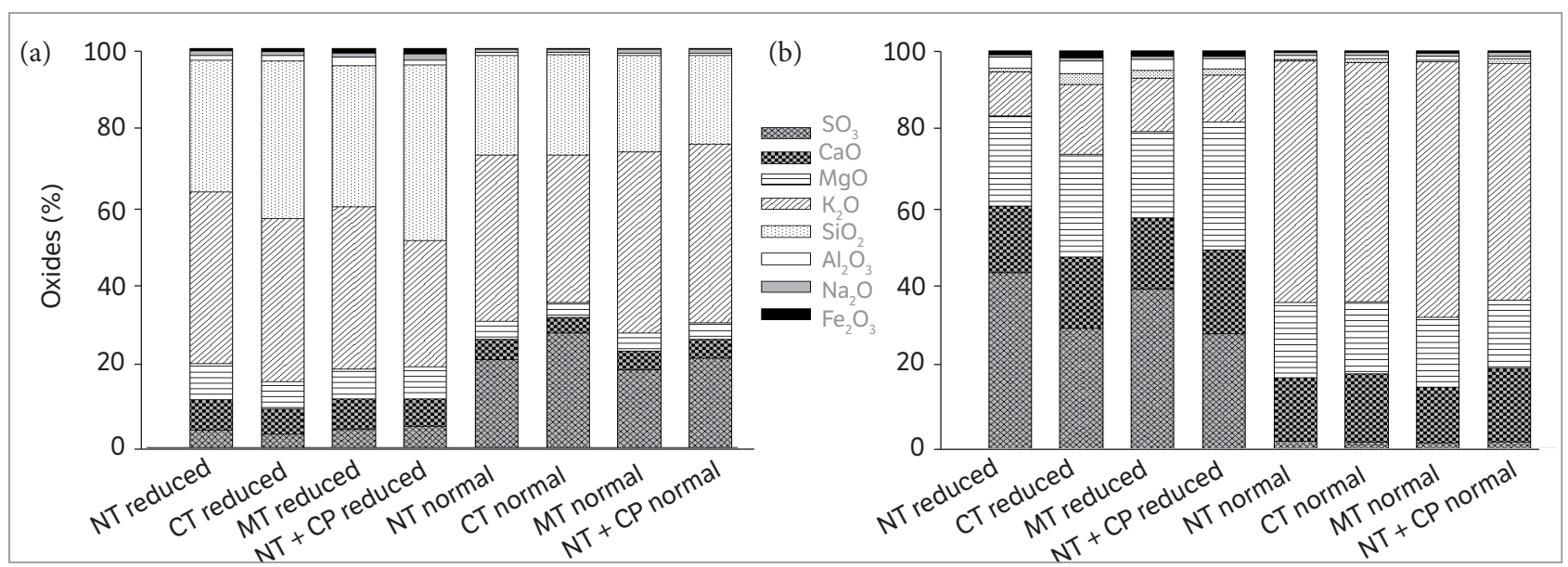

Figure 7. Ash composition (\%) of (a) oat and (b) soybean biomass cultivated in a Brazilian Oxisol, according to soil tillage methods and fertilizer rates (normal and reduced).

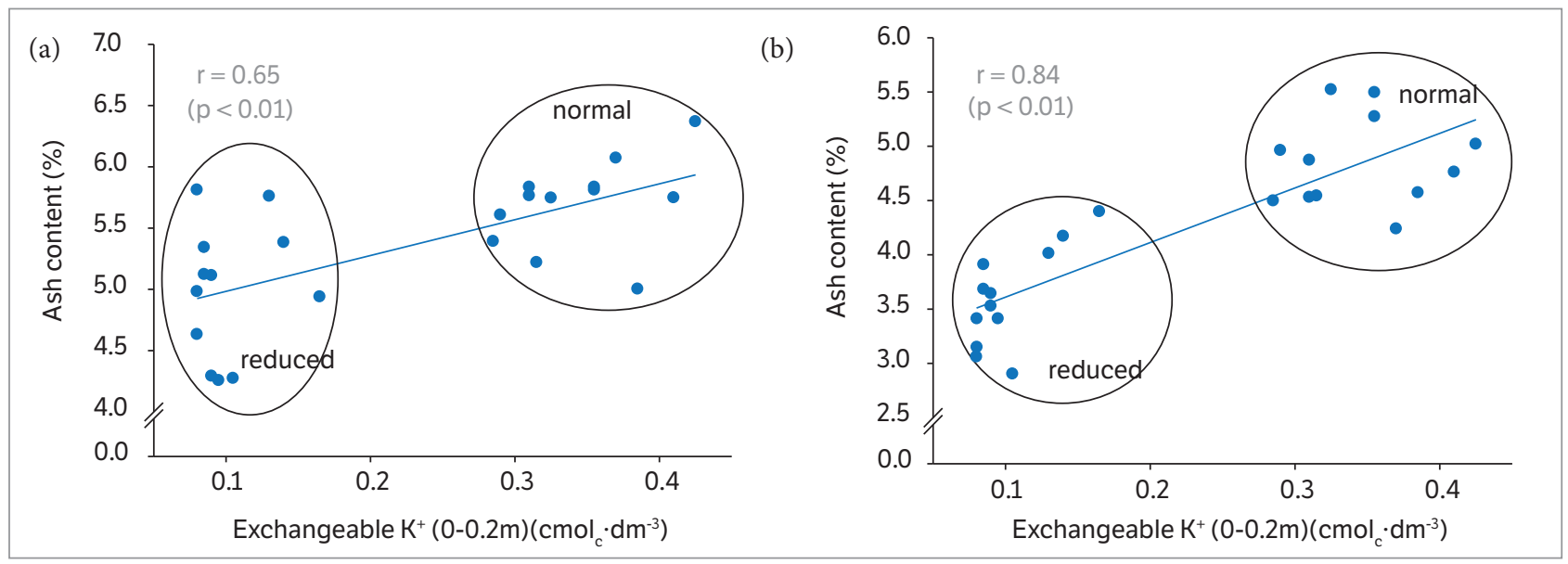

Figure 8. Pearson correlation $(p<0.01)$ between $(a)$ oat and $(b)$ soybean residual biomass ash contents and the exchangeable $K^{+}$in the arable layer (0-0.2 $\mathrm{m}$ ) of a Brazilian Oxisol, according to soil tillage methods and fertilizer rates (normal and reduced).

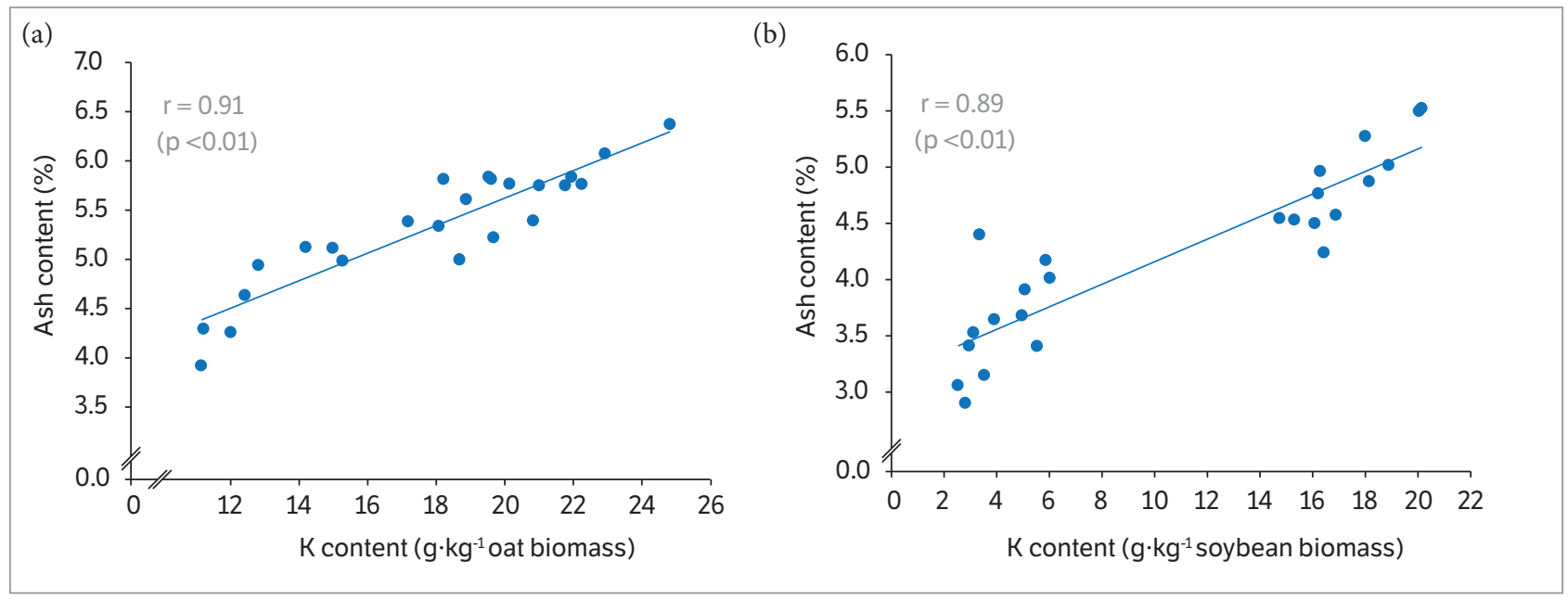

Figure 9. Pearson correlation $(p<0.01)$ between $(a)$ oat and $(b)$ soybean ash contents and the $K$ contents in the residual biomass. 
(Tan and Lagerkvist 2011). The ash content of residual biomass from agricultural crops is usually higher than forest species (Demirbas and Demirbas 2004). On the other hand this material is already produced and do not represent a competition with food production, as what happens with forestry biomass.

The HHV of oat and soybean residual biomass was not affected by soil tillage systems and fertilizer rates (Figs. $6 \mathrm{c}$ and $6 \mathrm{~d}$ ), which contradicts the initial hypothesis of this work. Despite the influence of the treatments on soil chemical attributes and on biomasses energetic quality, the highest ash contents observed in the normal fertilizer rate (Table 2) were not enough to affect HHV, although the inverse correlation between these two characteristics is often mentioned in the literature (Sheng and Azevedo 2005; Tan and Lagerkvist 2011).

The $\mathrm{C}$ and $\mathrm{H}$ contents are the elements positively related to HHV due to its high energetic density (Ambrosio et al. 2017; Demirbas and Demirbas 2004; Sheng and Azevedo 2005), while higher $\mathrm{O}$ contents tend to decrease the caloric value because it acts as an oxidizer agent. The contents observed to these elements ranged between 468 and $997 \mathrm{~kg} \cdot \mathrm{ha}^{-1}$ of C, 69 and $144 \mathrm{~kg} \cdot \mathrm{ha}^{-1}$ of $\mathrm{H}$, and 507 and $1063 \mathrm{~kg} \cdot \mathrm{ha}^{-1}$ of $\mathrm{O}$ to oat biomass; and 610 and $1214 \mathrm{~kg} \cdot \mathrm{ha}^{-1}$ of C, 92 and $182 \mathrm{~kg} \cdot \mathrm{ha}^{-1}$ of $\mathrm{H}$, and 678 and $1353 \mathrm{~kg} \cdot \mathrm{ha}^{-1}$ of $\mathrm{O}$ to soybean biomass. Again, the differences observed were a consequence of higher biomasses yields in NT and NT+CP tillage systems and normal fertilizer rate. Despite the significant and positive correlation between the $\mathrm{HHV}$ and the $\mathrm{C}$ concentration in the soybean biomass $(r=0.70, p<0.01)$ (Fig. 10), the treatments did not influence the $\mathrm{C}, \mathrm{H}$ and $\mathrm{O}$ concentrations (\%) of both residual biomasses (data not shown), which may explain the little variation observed in the HHV.

The biomass HHV, on average (17.9 $\mathrm{MJ} \mathrm{kg}^{-1}$ for oat and 18.2 $\mathrm{MJ} \mathrm{kg}^{-1}$ for soybean), was comparable to the HHV of forest species commonly used for firewood, like pine and eucalyptus (Telmo and Lousada 2011). The soybean HHV was slightly superior to that found in oat biomass, which can be attributed to a lignin content 2.4 times higher and ash content 1.3 lower (Sheng and Azevedo 2005) (Table 2), although the difference regarding the chemical fractions was not statistically evaluated. Soybean also had higher total residual biomass (Fig. 6b) and 15\% less K and 97\% less $\mathrm{Si}$ in its composition (Table 2), which suggests that this species presents a more favorable potential to energetic exploitation in relation to oat.

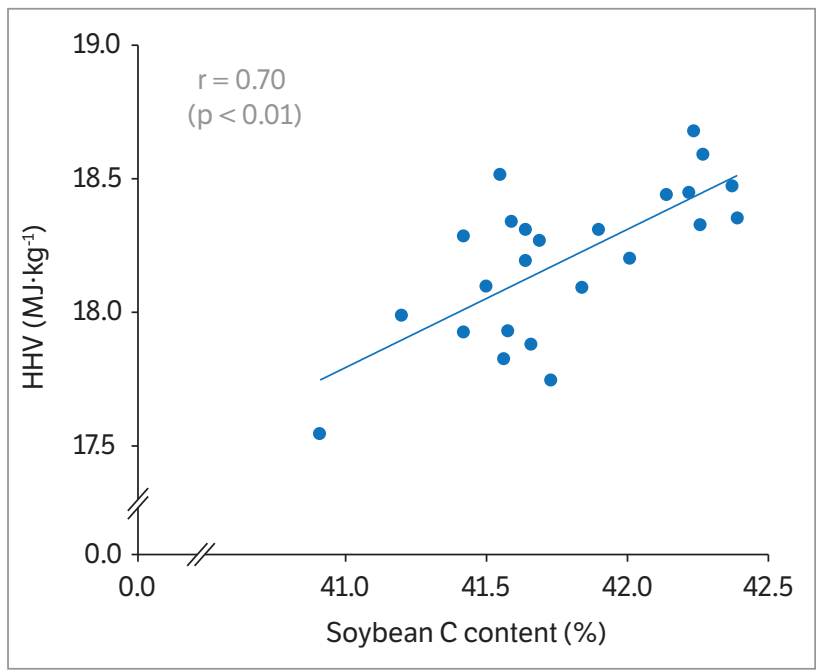

Figure 10. Pearson correlation $(p<0.01)$ between $C$ content $(\%)$ and Higher Heating Value (HHV) $\left(\mathrm{MJ}^{\mathrm{k}} \mathrm{kg}^{-1}\right)$ in a soybean biomass cultivated in a Brazilian Oxisol, according to soil tillage methods and fertilizer rates (normal and reduced).

Because there were no differences in HHV, the theoretical potential for electricity production obtained from the studied biomasses followed the same pattern observed in yields. Thus, the more biomass produced (in $\mathrm{NT}$ and $\mathrm{NT}+\mathrm{CP}$ for oat, and in normal fertilizer rate for both cultures), the greater the potential energy output per area unit (Figs. $6 \mathrm{c}$ and $6 \mathrm{~d}$ ). For this reason, the management that promotes highest grain yield (and consequently of residual biomass) should be adopted when the objective is the dual-purpose exploration of grain and energy.

Considering an agricultural season with oat (winter) followed by soybean (summer) in NT system and in normal fertilizer rate (collecting $30 \%$ of the residual biomass), the main harvested area in Paraná state during 2012/2013 (CONAB 2013) and the residential consumption of electricity in the Paraná state in 2013 as 6,986 GWh·year ${ }^{-1}$ (EPE 2014), the destination of residual biomass of the two crops could supply $42 \%$ of this demand (Table 3 ). This calculation considered a boiler efficiency of $20 \%$, although this value can reach up to $40 \%$ (Evans et al. 2010) and, hence, can be even more promising. This potential of energetic supply is inserted into a scenario that also encompasses the production of grains for human and animal consumption and the maintenance of $70 \%$ of the biomass above soil for its conservation in NT. Therefore, the energy exploration from agricultural residual biomass can significantly contribute to the energy matrix of countries with expressiveness in agriculture. 
Table 3. Residential electricity consumption that could be supplied by oat and soybean residual biomass in Paraná during the season of 2012/2013.

\begin{tabular}{|c|c|c|}
\hline Description & Unit & Value \\
\hline $\begin{array}{l}\text { aResidential consumption of } \\
\text { electricity }\end{array}$ & GWh & 6,986 \\
\hline 'Soybean harvested area ( $\dagger$ ) & ha & $4,752,800$ \\
\hline bOat harvested area ( $¥)$ & ha & 61,900 \\
\hline $\begin{array}{l}\text { cAverage theoretical potential for } \\
\text { electricity production from soybean } \\
\text { residual biomass (i) }\end{array}$ & $\mathrm{kWh} \cdot \mathrm{ha}^{-1} \cdot \mathrm{year}^{-1}$ & 612 \\
\hline $\begin{array}{l}\text { cAverage theoretical potential for } \\
\text { electricity production from oat } \\
\text { residual biomass (ii) }\end{array}$ & $\mathrm{kWh} \cdot \mathrm{ha}^{-1} \cdot \mathrm{year}^{-1}$ & 479 \\
\hline $\begin{array}{l}\text { dTheoretical potential for electricity } \\
\text { production from soybean residual } \\
\text { biomass }(\dagger \mathrm{x} i)(\mathrm{a})\end{array}$ & GWh.year-1 & 2,911 \\
\hline $\begin{array}{l}\text { dTheoretical potential for electricity } \\
\text { production from oat residual } \\
\text { biomass ( } ¥ x \mathrm{ii})(\mathrm{b})\end{array}$ & GWh.year-1 & 30 \\
\hline $\begin{array}{l}\text { Total theoretical potential for } \\
\text { electricity production }(a+b)\end{array}$ & GWh.year-1 & 2,941 \\
\hline $\begin{array}{l}\text { Residential consumption supplied } \\
\text { by residual biomass }\end{array}$ & $\%$ & 42 \\
\hline
\end{tabular}

\section{CONCLUSION}

After 23 years of management, the best soil fertility status obtained by tillage systems with none or less intense soil disturbance, added to normal fertilization rate, promoted changes in oat and soybean biomass composition. The differences, however, were not enough to modify neither their HHV nor their theoretical potential for electricity production. A synergic system with grain and energy production plus the permanence of soil coverage to no-tillage maintenance can be feasible in regions with high crop yields.

\section{ACKNOWLEDGEMENTS}

To the Coordination of Improvement of Higher Education Personnel (CAPES), for the scholarship granted to the first author, and to the National Council for Scientific and Technological Development (CNPq), for funding this research (Grant no. 482016/2012-4).

\section{AUTHOR'S CONTRIBUTION}

Conceptualization, Pierri L. and Pauletti V.; Formal Analysis, Pierri L., Roza L. A. and Saudade C. A. S.; Investigation, Pierri L., Pauletti V., Barth G. and Motta A. C. V.; Resources, Silva D. A.; Writing - Original Draft Pierri L., Pauletti V. and Motta A. C. V.; Writing - Review and Editing, Silva D. A., Motta A. C. V.; Supervision, Pauletti V., Barth G.; Funding Acquisition, Pauletti V.

\section{ORCID IDs}
L. Pierri
(iD) https://orcid.org/0000-0003-4233-7034
V. Pauletti
(iD) https://orcid.org/0000-0002-9231-7851
G. Barth
D https://orcid.org/0000-0002-8669-0588
A. C. V. Motta
D https://orcid.org/0000-0001-9117-1881
D. A. Silva
(iD) https://orcid.org/0000-0002-5433-1927
L. A. Roza
(iD) https://orcid.org/0000-0003-0005-2006
C. A. S. Saudade
(D) https://orcid.org/0000-0002-2881-1572

\section{REFERENCES}

[ABNT] Associação Brasileira de Normas Técnicas (1984). NBR 8633. Carvão vegetal: determinação do poder calorífico. Rio de Janeiro: ABNT.
Al-Kaisi, M. and Kwaw-Mensah, D. (2007). Effect of tillage and nitrogen rate on corn yield and nitrogen and phosphorus uptake in a corn-soybean rotation. Agronomy Journal, 99, 1548-1558. https://doi.org/10.2134/agronj2007.0012 
Ambrosio, R., Pauletti, V., Barth, G., Povh, F. P., Silva, D. A. and Blum, $H$. (2017). Energy potential of residual maize biomass at different spacings and nitrogen doses. Ciência e Agrotecnologia, 41, 626633. https://doi.org/10.1590/1413-70542017416009017

Andrews, S. S. (2006). Crop residue removal for biomass energy production: effects on soils and recommendations. USDA; [accessed 2013 October 3]. http://www.nrcs.usda.gov/Internet/ FSE_DOCUMENTS/nrcs142p2_053255.pdf

Berchielli, T. T., Sader, A. P. O., Tonani, F. L., Paziani, S. F. and Andrade, P. (2001). Avaliação da determinação da fibra em detergente neutro e da fibra em detergente ácido pelo sistema ANKOM. Revista Brasileira de Zootecnia, 30, 1572-1578. https://doi.org/10.1590/ S1516-35982001000600027

Blake, G. R. and Hartge, K. H. (1986). Bulk density. In G. W. Gee, J. W. Bauter and A. Klute (Eds.), Methods of Soil Analysis Part 1. Physical and Mineralogical Methods (p. 363-382). Madison: Soil Science Society of America, American Society of Agronomy.

Cifu, M., Xiaonan, L., Zhihong, C., Zhengyi, H. and Wanzhu, M. (2004). Long-term effects of lime application on soil acidity and crop yields on a red soil in Central Zhejiang. Plant and Soil, 265, 101-109. https://doi.org/10.1007/s11104-005-8941-y

[CONAB] Companhia Nacional de Abastecimento (2013). Acompanhamento da safra brasileira de grãos - v. 1 safra 2013/2014, no. 2. CONAB; [accessed 2015 February 3]. http://www.conab.gov. br/OlalaCMS/uploads/arquivos/13_11_11_08_54_13_boletim_ portugues_novembro_2013_-_ok.pdf

Congreves, K. A., Hayes, A., Verhallen, E. A. and Van Eerd, L. L. (2015). Long-term impact of tillage and crop rotation on soil health at four temperate agroecosystems. Soil and Tillage Research, 152, 17-28. https://doi.org/10.1016/j.still.2015.03.012

Demirbas, A. and Demirbas, A. H. (2004). Estimating the calorific values of lignocellulosic fuels. Energy Exploration and Exploitation, 22, 135-144. https://doi.org/10.1260/0144598041475198

Derpsch, R., Friedrich, T., Kassam, A. and Hongwen, L. (2010). Current status of adoption of no-till farming in the world and some of its main benefits. International Journal of Agricultural and Biological Engineering, 3, 1-26. https://doi.org/10.3965/j. issn.1934-6344.2010.01.0-0

Deubel, A., Hofmann, B. and Orzessek, D. (2011). Long-term effects of tillage on stratification and plant availability of phosphate and potassium in a loess chernozem. Soil and Tillage Research, 117, 85-92. https://doi.org/10.1016/j.still.2011.09.001
Dimassi, B., Mary, B., Fontaine, S., Perveen, N., Revaillot, S. and Cohan, J. P. (2014). Effect of nutrients availability and longterm tillage on priming effect and soil $\mathrm{C}$ mineralization. Soil Biology and Biochemistry, 78, 332-339. https://doi.org/10.1016/j. soilbio.2014.07.016

[EPE] Empresa de Pesquisa Energética (2014). Balanço Energético Nacional 2014: Ano base 2013. Rio de Janeiro: Ministério de Minas e Energia.

Evans, A., Strezov, V. and Evans, T. J. (2010). Sustainability considerations for electricity generation from biomass. Renewable and Sustainable Energy Reviews, 14, 1419-1427. https://doi. org/10.1016/j.rser.2010.01.010

Furlani, P. R. and Gallo, J. R. (1978). Determinação de silício em material vegetal, pelo método colorimétrico do "azul-de-molibdênio". Bragantia, 37, 5-11.

Kibet, L. C., Blanco-Caqui, H. and Jasa, P. (2016). Long-term tillage impacts on soil organic matter components and related properties on a Typic Argiudoll. Soil and Tillage Research, 155, 78-84. https:// doi.org/10.1016/j.still.2015.05.006

Kollmann, F. F. P. and Cotê, W. A. (1968). Principles of wood science and technology. 1st ed. New York: Springer.

Martins, A. P. L. and Reissmann, C. B. (2007). Material vegetal e as rotinas laboratoriais nos procedimentos químico-analíticos. Scientia Agraria, 8, 1-17. https://doi.org/10.5380/rsa.v8i1.8336

Mbuthia, L. W., Acosta-Martínez, V., DeBruyn, J., Schaeffer, S., Tyler, D., Odoi, E., Mpheshea, M., Walker, F. and Eash, N. (2015). Long term tillage, cover crop, and fertilization effects on microbial community structure, activity: Implications for soil quality. Soil Biology and Biochemistry, 89, 24-34. https://doi.org/10.1016/j. soilbio.2015.06.016

Messiga, A. J., Ziadi, N., Morel, C., Grant, C., Tremblay, G., Lamarre, G. and Parent, L. E. (2012). Long term impact of tillage practices and biennial $\mathrm{P}$ and $\mathrm{N}$ fertilization on maize and soybean yields and soil P status. Field Crops Research, 133, 10-22. https://doi. org/10.1016/j.fcr.2012.03.009

Nogueira, L. A. H. and Lora, E. E. S. (2003). Dendroenergia: fundamentos e aplicações. 2nd ed. Rio de Janeiro: Interciência.

Pauletti, V., Lima, M. R., Barcik, C. and Bittencourt, A. (2005). Chemical attributes evolution of an Oxisoil under different tillage methods. Scientia Agraria, 6, 9-14. https://doi.org/10.5380/rsa.v6i1.4582 
Raij, B van, Andrade, J. C., Cantarella, H. and Quaggio, J. A. (2001). Análise química do solo para avaliação da fertilidade de solos tropicais. 1st ed. Campinas: Instituto Agronômico de Campinas (IAC).

[SEAB] Secretaria da Agricultura e do Abastecimento do Paraná (2013). Departamento de Economia Rural (DERAL). Precipitação pluviométrica regional (2012/2013); [accessed 2013 December 19]. http://www.agricultura.pr.gov.br/modules/conteudo/conteudo. php?conteudo $=74$

Sheng, C. and Azevedo, J. L. T. (2005). Estimating the higher heating value of biomass fuel from basic analysis data. Biomass and Bioenergy, 28, 499-507. https://doi.org/10.1016/j. biombioe.2004.11.008

Sisti, C. P. J., Santos, H. P., Kohhann, R., Alves, B. J. R., Urquiaga, S. and Boddey, R. M. (2004). Change in carbon and nitrogen stocks in soil under 13 years of conventional or zero tillage in southern Brazil. Soil and Tillage Research 76, 39-58. https://doi.org/10.1016/j. still.2003.08.007

Tan, Z. and Lagerkvist, A. (2011). Phosphorus recovery from the biomass ash: a review. Renewable and Sustainable Energy Reviews, 15, 3588-3602. https://doi.org/10.1016/j.rser.2011.05.016
Telmo, C. and Lousada, J. (2011). Heating values of wood pellets from different species. Biomass and Bioenergy, 35, 2634-2639. https://doi.org/10.1016/j.biombioe.2011.02.043

Valboa, G., Lagomarsino, A., Brandi, G., Agnelli, A. E., Simoncini, S., Papini, R., Vignozzi, N. and Pellegrini, S. (2015). Long-term variations in soil organic matter under different tillage intensities. Soil and Tillage Research, 154, 126-135. https://doi.org/10.1016/j.still.2015.06.017

Vogeler, I., Rogasik, J., Funder, U., Panten, K. and Schnug, E. (2009). Effect of tillage systems and P-fertilization on soil physical and chemical properties, crop yield and nutrient uptake. Soil and Tillage Research, 103, 137-143. https://doi.org/10.1016/j.still.2008.10.004

Zhang, H. M., Yang, X. Y., He, X. H., Xu, M. G., Huang, S. M., Liu, H. and Wang, B. R. (2011). Effect of long-term potassium fertilization on crop yield and potassium efficiency and balance under wheatmaize rotation in China. Pedosphere, 21, 154-163. https://doi. org/10.1016/S1002-0160(11)60113-6

Zhang, S., Chen, X., Jia, S., Liang, A., Zhang, X., Yang, X., Wei, S., Sun, B., Huang, D. and Zhou, G. (2015). The potential mechanism of long-term conservation tillage effects on maize yield in the black soil of Northeast China. Soil and Tillage Research, 154, 84-90. https://doi.org/10.1016/j.still.2015.06.002 